\title{
Challenges of Organizational Learning: Perpetuation of Discrimination Against Employees with Disabilities
}

\author{
Lynn Perry Wooten* and Erika Hayes James ${ }^{\dagger}$
}

This article examines why organizations struggle with learning how to prevent discrimination against their employees with disabilities. To explore this issue, qualitative archival data were collected and analyzed from 53 Americans with Disabilities Act (ADA) lawsuits filed against 44 organizations. Theoretical analysis of the qualitative data suggests that several organizationally based learning theories explain the difficulty organizations have with creating a disability-friendly work environment. These barriers to learning are embedded in complex defense mechanisms and discriminatory organizational routines. Furthermore, organizations have difficulties engaging in higher-order and vicarious learning. We conclude the article with examples of successful learning practices as they relate to barriers identified in the qualitative analysis. Copyright $(C) 2005$ John Wiley \& Sons, Ltd.

\section{INTRODUCTION}

Although it has been over a decade since President George H. W. Bush signed the Americans with Disabilities Act of 1990 (ADA), organizations are still grappling with creating a work environment that accommodates the needs of their employees with disabilities, while leveraging their talents and skills. The ADA was the world's first comprehensive civil rights law prohibiting discrimination against people with disabilities in the workplace and requiring organizations to provide reasonable accommodations for disabled workers. Legislators hoped the ADA would ensure people with disabilities had access to lines of work from which they traditionally had been excluded (DeLeire, 2001). In other words, the ADA's goal was to increase job opportunities, and enable disabled employees to experience satisfying careers and achieve their full potential in the workplace (Stone \& Colella, 1996).

*Correspondence to: Lynn Perry Wooten, Assistant Professor of Corporate Strategy/International Business, School of Business, University of Michigan, 701 Tappan Street, Ann Arbor, MI 481091234, U.S.A. E-mail: lpwooten@umich.edu

${ }^{\dagger}$ Erika Hayes James is an Associate Professor of Business Administration, Darden School of Business, University of Virginia, Charlottesville, VA 22906, U.S.A. Telephone: 434-924-4796. E-mail address: JamesE@darden.virginia.edu 
Current statistics indicate successful ADA implementation is a work in progress for most organizations and, thus, a learning opportunity. For instance, only onethird of Americans with disabilities are employed, although two-thirds of those unemployed would prefer to work (National Organization on Disability, 2003). Those working disabled employees have earnings less than non-disabled employees and many disabled workers are employed in part-time or low-status jobs providing little chance for advancement (Braddock \& Bachelder, 1994).

The passage of the ADA has generated numerous lawsuits and charges filed with the Equal Employment Opportunity Commission (EEOC). Since the enforcement of the Act began in 1992, the EEOC has received over 189,000 discrimination complaints, averaging about 16,000 complaints filed per year and representing $19 \%$ of the EEOC's caseload (EEOC, 2004b). When an ADA charge is filed with the EEOC, the legal process begins with an investigation of the initial facts that support the violation. At this stage, $60.6 \%$ of the complaints filed are dismissed by EEOC staff (EEOC, 2004a). In addition, 17.6\% of ADA complaints are discontinued due to administrative closure, such as via withdrawal, the failure to locate the charging party, the charging party refusing to accept full relief, or the outcome of a related litigation establishing a precedent, making the charge futile (EEOC). ${ }^{1}$ In other instances, the charging party withdraws the case upon receipt of the requested benefit. If, after an investigation, the evidence establishes that discrimination has occurred, the EEOC can seek to settle the charge through mediation or litigation. Interestingly, defendants prevail in more than $93 \%$ of reported ADA employment discrimination cases at trial and $84 \%$ of appeals from the trial court (Colker, 2001).

The monetary and public relations costs associated with an ADA out-of-court settlement or lawsuit can be significant. This is evident in the $\$ 300$ million that the EEOC has obtained for ADA violations through its enforcement efforts, which include settlements, conciliation, mediation, and litigation (Crampton \& Hodge, 2003). In addition, more than 10,000 disabled employees have received nonmonetary settlements for training, policy changes, and workplace accommodations (Crampton \& Hodge, 2003). Organizations choosing not to comply with the ADA may be perceived as expressing values of intolerance for workforce diversity (Hall \& Hall, 1994).

The difficulty of managing a diverse workforce and the inability to prevent employee discrimination is surprising given the widespread focus on the benefits of diversity management from scholarly and practitioner communities (Souza, 1997; Hemphill \& Haines, 1997). With increased information about workforce diversity, organizations should have a better understanding of how to prevent discrimination and create a work environment that accommodates the needs of disabled employees. However, the number of ADA charges filed with the EEOC and the courts suggests that organizations struggle with learning how to create an inclusive working environment for their disabled employees. Organizations with this learning challenge remain susceptible to future discrimination lawsuits and reduce the effective utilization of their human capital pool.

Based on this premise, this article explores why organizations fail to comply with Title I of the ADA, which prohibits discrimination against workers with disabilities.

\footnotetext{
${ }^{1}$ This figure has been consistently on the decline since it was at $70.5 \%$ in 1992 (EEOC).
} 
We contend that failures in eliminating disability discrimination reflect difficulties of organizational learning. Consistent with the EEOC, and for the purposes of this paper, we define discrimination of the disabled in organizations as the less than favorable or unfavorable treatment of an employee or job applicant with a physical or mental impairment that substantially limits a major life activity. This definition takes into account unfavorable treatment resulting from neutral employment policies and practices that do not reasonably accommodate the needs of disabled employees, such as work schedules, the layout of facilities or equipment, and job design.

In the following sections, this article examines the linkage between organizational learning theories and the failure to comply with Title I. Our observations are based on a multi-case study using newspaper accounts of disability discrimination in the workplace. Through qualitative analysis, we identify themes in the case studies that demonstrate behaviors that prevent organizations from learning how to manage and resolve workplace discrimination of employees with disabilities. The article concludes with examples from the data of successful learning practices.

\section{ORGANIZATIONAL LEARNING PERSPECTIVES}

Organizations learn by encoding inferences from past experiences into routines that guide behavior (Levitt \& March, 1988). This process of learning involves knowledge acquisition, information distribution, information interpretation, and the development of an organizational memory (Huber, 1991). In many instances, organizational learning results from a detection or correction of errors (Argyris, 1977). When an organization has a problem, members actively engage in knowledge acquisition and searching for a strategy to resolve the problem (Argyis \& Schon, 1978).

However, successful problem resolution and organizational learning is dependent upon the organization's ability not only to acquire knowledge, but also to respond and adapt its behavior. Organizational learning requires the organization to adapt continuously to a changing business environment by drawing on knowledge-a repertoire of skills and routines - that influences decision-making. In this sense, learning relates to an organization's ability to encompass both processes and outcomes into its mental model - a set of ingrained assumptions defining how managers understand the world and respond to problems (Dodgson, 1993; Senge, 1990). Organizations learn from their mental models as they become a part of the organization's memory and routines. Mental models can be tacit or explicit and evident in an organization's culture, policies, and practices. For example, some organizations develop mental models that handle discriminatory behavior and harassment of disabled employees through accepting the status quo and not changing the situation (James \& Wooten, 2000). This was the case in the Olive Garden lawsuit where management's mental model entailed ignoring incidents when an employee was subjected to almost daily physical and verbal abuse relating to his mental retardation.

Management scholars have identified two types of organizational learning (Argyris \& Schon, 1978; Senge, 1990). In single-loop learning, the organization adapts to a situation by taking corrective actions for a problem (e.g. accommodation 
for a single individual) without questioning or changing the present policies (e.g. universal design of the facility). This is the short-term, reactive viewpoint of organizational learning that does not examine the appropriateness of current behaviors (Yogesh, 1998). In double-loop or reflective learning, the organization's solution involves modifying underlying norms, policies, and objectives. This type of organizational learning demands a re-examination of and reflection upon fundamental values. Many organizations when confronted with the discrimination of a disabled employee adopt a single-loop learning strategy. Monetary settlements are paid, jobs are reinstated, or changes are made to accommodate the disabled employee. However, few examine the underlying cause of the discriminatory behavior in resolving the issues. This may demand a change in human resource management practices, instilling new cultural values.

\section{Discrimination Crises as Learning Opportunities}

Most organizations have difficulties with modifying policies and routines that become salient when organizations confront crises such as discrimination lawsuits (Nystrom \& Starbuck, 1984; Wooten \& James, 2004). This is because discrimination crises occur infrequently and are often a surprise to organizational members. These crises demand the organization's resources and require a decision or judgment intended to improve the situation (Jackson \& Dutton, 1987; Aguilera, 1990).

When accusations of discrimination in the workplace become public, organizations must take action to address the concerns of various stakeholders and prevent future crises (James \& Wooten, 2000). If organizations do not learn from a discrimination crisis, they run the risk of stigmatization. Historically, discrimination is a socio-politically charged issue differing from other types of organizational crisis, such as product recalls or technological failures (James \& Wooten, 2000). Furthermore, failure to learn from a discrimination crisis can have direct and indirect consequences on the organization's recruitment pool, reputation with customers, and employee commitment and institutional support (Wright, Ferris, Hiller, \& Kroll, 1995). To prevent similar crises in the future, management must discern and rectify the weak points in its human resource management practices or social system (Pearson \& Mitroff, 1993).

Lawsuits and complaints of ADA violations provide one research context of organizational crises that may help to identify barriers to organizational learning. Legal grievances by disabled employees typically represent the consequence of egregious diversity mismanagement practices. There is a strong likelihood that organizations can successfully learn to change their actions because management practices are simply behaviors.

Discrimination in the workplace is a serious and challenging aspect of managing workforce diversity and demands a complex skill set. This is especially true in the context of discrimination against disabled employees compared to other forms of discrimination. In the past, organizations concentrated their diversity management efforts on ethnic and gender issues and paid little attention to the unique issues associated with disabled individuals in the workforce because the adoption of human resource management polices is driven by workforce competition and pressures from dominant coalitions (Macy, 1996; Stone \& Colella, 1996). 
Moreover, discrimination against employees with disabilities is represented in case studies that illustrate how organizations learn, or fail to learn, which help researchers and practitioners understand the documented organizational behavior influenced by stakeholders (Eisenhardt, 1989). Although disability discrimination cases are infrequent occurrences in organizations and account for a small percentage of EEOC charges, they provide unique opportunities to understand how organizations manage a diverse workforce, since most diversity research focuses on gender or race issues.

\section{METHODOLOGY}

Qualitative research methodology allows researchers to gain a holistic overview of the research's context and capture data on the perceptions of various stakeholders (Wolcott, 1994; Blanck \& Schartz, 2001). Qualitative research enables the researcher to understand social life by identifying and elaborating on social process theories as they unfold in the data (Glaser \& Strauss, 1967; Locke, 2001). We employ a multi-case study methodology to identify patterns of organizational barriers preventing firms from learning how to manage and resolve disabled employee discrimination in the workplace.

\section{Data Collection}

During the Fall of 2003 and Winter of 2004, the researchers used the ABI/Proquest and Factiva databases to identify articles depicting disabled employee discrimination. Articles were collected for a 5 year time period that included January 1, 1998, to December 31, 2003. ABI/Proquest and Factiva are both subscription databases sold to university and corporate libraries. ABI/Proquest contains nearly 1,800 business periodicals and provides information access for over 60,000 companies with business and executive profiles. The article coverage dates back to 1971 and articles are updated daily. Similar to ABI/Proquest, the Factiva database offers company and industry financial data and news stories. This database is a joint venture of the Dow Jones and Reuter News Services. It indexes full text articles in 9,000 trade publications, newspapers, newswires, and magazines. Many of these articles are updated daily from 120 newswire services. In addition to these databases, press releases of disabled employee discrimination lawsuits were coded from the EEOC website. The archival data collected for this study were part of a larger research project that examined not only disabled employee discrimination, but also race, age, religion, and gender discrimination in the workplace.

For each database, the authors performed a keyword Boolean search using combinations of the words or phrases discrimination, EEOC, ADA, disability/ disabled, and employee. This search in the databases yielded a sample 44 organizations representing 53 lawsuits; five organizations within the sample had multiple lawsuits or EEOC charges. The organizations in our sample and the type of discrimination charge filed are presented in the appendix. The sample represents organizations of varying sizes, types, and industries. Fifteen percent of the organizations are non-profit or governmental (e.g. Naperville City Government, Palm Beach County, and United Blood). Many corporations within the sample are well known 
service or retail organizations (e.g. AT\&T, Hertz, Sears, UPS, and Wal-Mart). Other firms are regional competitors within their industry or small businesses (e.g. Anderson Fuel \& Lubricants, Fred Meyers, and Life Companion). Physical disability discrimination charges represent $81 \%$ of our sample. The remaining charges are for discrimination of mental disabilities (18\% of the cases) and substance abusers ( $1 \%$ of the cases). Approximately $50 \%$ of the charges regarded job termination or reasonable accommodations. Pre-employment discrimination, job demotion/discrimination, harassment, and benefits denial account for the other half of the charges. ${ }^{2}$

For each media account of a disabled employee discrimination lawsuit or EEOC complaint, we analyzed documentation regarding the allegation and the organization's human resource management policies. Although the majority of our data was collected from media accounts, we supplemented the media account data with annual reports, corporate websites, and public relations materials. We recognize that mediabased accounts and organization documentation may have inherent biases due to the content and process norms that exist for reporting to various audiences and stakeholders. In addition, media accounts of ADA employment grievances or lawsuits restrict our sample to large organizations and limit cases from lower courts.

Despite these weaknesses, media accounts and organizational documents provide rich insights into how an organization's dominant coalition interprets and communicates its actions. These data are often more comprehensive than the material a researcher would obtain from a questionnaire or an interview, and provide formal documentation on how an organization defines its management practices (Forster, 1994). Moreover, media accounts represent a collaborative effort where reporters negotiate with sources to depict an accurate story by presenting various angles of an incident (Miller, 2000). To ensure validity and consistency in the data, we triangulated from multiple sources of media accounts. This included national, regional, and local newspapers, EEOC press releases, and transcripts from radio and news broadcasts regarding the discrimination case.

\section{Data Coding and Analysis}

The study's data collection includes analysis of over 150 pages of newspaper/journal articles, press releases, and organizational documents. For each article, we coded (1) the organization's name, (2) the employee's disability, (3) the type of discrimination charge, and (4) the organization's strategies for responding to discrimination charges. To code the data, we used an open-ended coding process to examine the data for similar themes, so as to understand the barriers to learning how to manage and resolve workplace discrimination of disabled employees (Miles \& Huberman, 1984; Strauss \& Corbin, 1998). This open-ended coding allowed the researchers to organize the data in an iterative manner by fitting accounts into categories and refining categories as new themes emerged. The method of coding and analysis, described as a template analytical technique, considered established frameworks to analyze the data (Boyatzis, 1998).

The authors and one research assistant coded the data using protocols employed in consensual qualitative research (Hill, Thompson, \& Williams, 1997). First, the

\footnotetext{
${ }^{2}$ See the appendix for a description of the attributes of the sample.
} 
Table 1. Learning barriers

\begin{tabular}{|c|c|c|}
\hline Learning barrier & $\begin{array}{l}\text { Percentage } \\
\text { of cases }\end{array}$ & Coding schema \\
\hline $\begin{array}{l}\text { Discriminatory } \\
\text { organizational routes }\end{array}$ & $43.8 \%$ & $\begin{array}{l}\text { - Harassment or perpetuation of negative behavior towards } \\
\text { disabled employees } \\
\text { - Unwillingness to provide reasonable accommodations } \\
\text { - Lack of an infrastructure to support disabled employees } \\
\text { - Negative images of disabled employees } \\
\text { - View that disabled employees depleted } \\
\text { organizational resources }\end{array}$ \\
\hline $\begin{array}{l}\text { Organizational } \\
\text { defense routines }\end{array}$ & $37.5 \%$ & $\begin{array}{l}\text { - Denying discrimination exists } \\
\text { - Disassociating from discriminatory behaviors } \\
\text { - Defending management practices that discriminate } \\
\text { - Referencing organizational policies that justify } \\
\text { discrimination } \\
\text { - Justifying discrimination because of workplace } \\
\text { safety concerns }\end{array}$ \\
\hline $\begin{array}{l}\text { Reliance on } \\
\text { reactive learning }\end{array}$ & $14.6 \%$ & $\begin{array}{l}\text { - Repeat offenses } \\
\text { - Minimal ADA compliance in a response to a legal mandate } \\
\text { - Not addressing the underlying cause of discrimination } \\
\text { - Myopic focus on strategic goals, such as cost minimization }\end{array}$ \\
\hline Window dressing & $4.1 \%$ & $\begin{array}{l}\text { - Pretense or surface commitment to disabled employees } \\
\text { - Advertising policies that include the disabled } \\
\text { - Focusing on impression management with regards } \\
\text { to disabled employees }\end{array}$ \\
\hline Lack of vicarious learning & g N/A & $\begin{array}{l}\text { - Lack of reference points for managing disabled employees } \\
\text { - Lack of interest group mobilization for ADA violation }\end{array}$ \\
\hline
\end{tabular}

data coding team worked independently to code a dominant learning barrier for each account. We then met as a team to compare results. When a team member disagreed on the classification, the discrepancies were discussed and consensus was reached through reference back to the original media accounts. Our data analysis identified five barriers to learning for the prevention of disabled employee discrimination. These barriers are described in Table 1 .

\section{Coding Results}

The most frequent codes for barriers to learning were discriminatory organizational routines $(43.8 \%$ of the cases) and organizational defense routines $(37.5 \%$ of the cases). Examples of discriminatory organizational routines include harassment of disabled employees, unwillingness to provide reasonable accommodations, and negative images of disabled employees. Discriminatory routines were not only prevalent during employment, but also in pre-hiring practices. The coding schema for organizational defense routines included management's denial or justification of discrimination and management's disassociation from the discriminatory behaviors. Our data analysis indicated that the organizations in the sample often used defense routines as a strategy to justify job termination or demotion of a disabled employee.

"Reliance on reactive learning" ( $14.6 \%$ of cases) and "window dressing" (4.1\%) were additional codes identified in our data analysis. Cases were coded as reactive learning if the organization failed to address the underlying cause of discriminatory 
behavior or if it had a myopic focus on strategic goals while neglecting to develop an inclusive work environment. In many instances, these defendants were alleged repeat offenders for $\mathrm{ADA}$ violations and other types of employee discrimination (e.g. race, gender, age, or religion) such as Wal-Mart, UPS, and General Motors. The window-dressing code refers to cases where the organization focused on impression management or a surface-level commitment with regards to disabled employees. Organizations employing the window-dressing strategy were nonprofits, government agencies and retailers.

"Lack of vicarious learning" was the fifth and final category that emerged from our data coding. Unlike race and gender cases, we were unable to identify any examples of pressures from external stakeholders, with the exception of the EEOC. However, from our past research on discriminatory employment practices, we found that class action race or gender cases witnessed pressures from interest groups, and the organization was more likely to change its discriminatory practices and improve its human resource management policies (James \& Wooten, 2000). Learning from the previous mistakes of other organizations and the pressure of interest groups overrides the natural tendency to evade problems or adopt defensive response strategies (Edelman \& Suchman, 1997).

The next section elaborates on the learning barriers identified in our data analysis by drawing on theories and integrating examples from the media accounts.

\section{BARRIERS TO LEARNING}

The adaptive organizational learning perspective assumes learning is a function of changing behavior in response to experience or as a result of failure (Glynn, Lant, \& Milliken, 1994; Levitt \& March, 1988). This assertion is based on the central tenet that organizational behavior builds upon history dependent routines and achievement of predetermined goals. These experiential history lessons are captured in organizational routines, such as rules, procedures, strategies, and work ideologies, and are the result of organizations focusing their learning activities and environmental interpretations on the past rather than on the future.

This cognitive entrenchment in the past prevents organizations from learning to change their routines and experimenting with new ones. Therefore, dysfunctional routines are likely to cease when they are associated with failure (e.g. inability to meet targets) and functional ones to continue or increase when they are associated with success (Cyert \& March, 1963). The adaptive learning perspective gives rise to potential barriers, which may explain an organization's failure to effectively manage and prevent disabled employee discrimination lawsuits. In addition, the trial and error experimentation, which can facilitate organizational learning, may not fully apply when learning is associated with non-routine events, such as disabled employee discrimination.

\section{Discriminatory Organizational Routines}

Central to the adaptive learning approach is the significance of routines explaining organizational behavior. This conceptualization helps us to understand an organization's failure to learn how to manage discrimination lawsuits. From 
analyzing our case studies, we found several examples of organizational routines as barriers to learning. At a basic level, some organizations simply lacked routines within their repertoire to manage the challenges of discrimination. This is especially true for the discrimination of disabled employees since organizations have exerted more energy in handling ethnic and gender discrimination issues (Macy, 1996).

Lack of organizational routines focusing on disabled workers may stem from the "ableness" principle constructed in the U.S. workplace. This leads to the exclusion of those perceived as "disabled" based on the idea that these individuals are incompetent or incapable of performing in the workplace (Harlan \& Robert, 1998). With the social construction of a work environment emphasizing "ableness," organizations have neglected to develop routines to accommodate persons with disabilities (Blanck et al., 2003).

Instead, organizational routines become defined as how the majority of workers view the world or approach tasks (Hall \& Hall, 1994). R. R. Donnelley \& Sons' discrimination of David Mateski illustrates the failure to develop routines for managing disabled workers. Mateski, a graphic technician with paraplegia, was dismissed after one day from his temporary employment because he needed to go home after encountering a rare incontinence problem (EEOC, 2002). In the pre-trial discovery, it was revealed that R. R. Donnelley had not trained its managers on policies regarding disability discrimination and, consequently, the managers were unaware that antidiscriminatory policies extended to temporary employees (Workforce, 2003).

Similar to the Donnelley case, Target Corporation failed to create an infrastructure to accommodate job assignments for its disabled workers. In the Target case, employee Susan Stombaugh had multiple sclerosis and was refused a vacant alternative job after her disability interfered with performance in her current job (EEOC, 2003). Although Target had vacant jobs that would accommodate Burchett's disability, she was denied a transfer. Thus, management did not consider how using this transfer policy could accommodate employees with disabilities and prevent violation of the ADA. However, the Supreme Court's decision in Airways, Inc. v. Barnett, 535 U.S. 391, 122 S. Ct 1516 (2002) now provides organizations with some guidelines regarding transfer policy and reasonable accommodations for disabled employees. The court held that when a requested accommodation conflicts with the rules of a seniority system it makes the accommodation unreasonable. However, the plaintiff may present evidence of special circumstances that make reasonable exception to an employer's seniority rule.

In other organizations, existing discriminatory routines consciously perpetuate negative behavior and act as a barrier to learning (Wooten \& James, 2004). When unspoken norms become routine in the organization, a dangerous behavior pattern emerges within the culture, which leaves the organization vulnerable to allegations of discrimination. The institutionalization of discriminatory routines produces a work environment where disabled employees are perceived as "damaged goods" or "second-class citizens," unable to make competent decisions or perform their job duties in a cost-effective manner (Boyle, 1997).

These discriminatory routines may be manifested in employee harassment, such as Linda Robel's experience at a Fred Meyer grocery store. Robel was given a light duty assignment for back problems sustained from a workplace injury. Her coworkers laughed at her and acted out a slip and fall (Robel v. Roundup Corp., 2002). Even after the store director warned employees that future harassment could result 
in termination, co-workers continued to harass Robel. Although one employee was terminated for harassment, the harassment escalated when Robel received a 2 week work release from her physician. When leaving work, she overheard an employee comment to other deli workers, "Can you believe it, Linda going sit on her big XXX and get paid" (18883-3-III, Linda Robel v. Roundup Corporation D/B/a Fred Meyer, Inc.). It is possible in the Fred Meyer case that organizational members believed the disabled employee was depleting resources or receiving unjustifiable favorable treatment, thus encouraging the discriminatory routines (Fine \& Asch, 1988). However, if this assumption is true, it was management's responsibility to clarify this myth and define a vision for changing the company's mindset for accommodating workers with disabilities (Cox, 2001).

The Wal-Mart cases in our study indicate another instance of an organization struggling with learning to prevent disabled employee discrimination. Our sample includes seven violations of the civil rights of Wal-Mart employees with disabilities. Interestingly, Wal-Mart's discriminatory routines have not gone unnoticed by EEOC spokespersons. As one spokesperson stated, "This is more violations than any other single employer" (Higuria \& Star, 2001). Similarly, EEOC former chair Ida Castro chastized the company, "It is extremely troubling that one of the nation's largest employers continues to show a reckless disregard for the statutory rights of individuals with disabilities" (Schafer \& Helderman, 2001). In the context of WalMart, its size, bureaucratic structure, and focus on a low-cost strategy likely reinforce its discriminatory routines (Alder, 1999). Wal-Mart's structure and strategy depict the "negative side" of bureaucracy, where the rigid rules, hierarchy, and efficiency goals come at the expense of alienating and discriminating against employees (Alder \& Borys, 1996).

\section{Organizational Defensive Routines}

In addition to discriminatory routines acting as a barrier to learning, we found that organizations in our study employed defensive routines to justify their discriminatory practices. Organizational defensive routines are actions, policies, and norms of behavior preventing organizations from experiencing embarrassment or threat (Argyris, 1990). These organizational defenses hinder management from taking responsibility for their decisions. Instead, organizations defend themselves against ineffectiveness by blaming others (Rahim, 1997).

Argyris (1990) characterized organizational defensive routines as anti-learning, and suggested that when an organization is confronted with threatening or embarrassing information as a result of its own behavior defense routines will bypass or cover up the information. The organization subsequently offers excuses maintaining the cover-up. This tendency to cover-up negative information may result in missed learning opportunities and the continuation of the behavior that caused the initial problem. By employing these types of defensive routine, organizations hope to preserve a favorable image and disassociate themselves from the negative event (Schlenker, 1980; Elsbach \& Sutton, 1992; Elsbach, 1994).

Consistent with Benoit (1995), we found it common for spokespersons to deny the problem by stating the incident "did not occur" or the organization "was not responsible." In many instances these statements to the media were legal or public 
relations strategies to avoid responsibility and minimize liability. Thus organizations respond to legal incentives or penalties by developing defenses and exploiting loopholes to escape sanctions (Edelman \& Suchman, 1997). Consequently, these defense mechanisms employed as legal strategies legitimate corporate policies and influence organizational norms.

The DiSanto v. McGraw-Hill, Inc. disability lawsuit serves as an illustration of defensive routines. In DiSanto (2000), after a jury initially found that McGraw-Hill violated the ADA when an employee was terminated after he informed his manager he was HIV positive, the company spokesman stated that "McGraw-Hill will challenge the verdict and if necessary appeal. From our viewpoint, there is no basis in fact or law for the damages. The award reflected sympathy for an individual with a very serious medical condition" (McMorris, 1999). ${ }^{3}$

In other ADA violations, organizations defend their management practices by challenging the disability or how the disability should be treated in the workplace. For example, in Fraser v. Goodale (2003), U.S. Bancorp denied a senior account specialist with diabetes the right to eat food at her desk during her workday if her blood sugar dropped too low. Consequently, she passed out in the bank's lobby. Nonetheless, management justified its policies. The bank argued that instead of desk breaks the senior account specialist could carry her meals and insulin in a backpack and eat in the breakroom (Fraser v. Goodale).

In another lawsuit, McDonald's defined what it considers a disability, and contended the company was not in violation of ADA when it did not hire an obese job applicant, Joseph Connor, by stating, "Connor's obesity was due to a physiological disorder, it does not constitute a 'physical impairment,' and thus does not fall under the strictures of the ADA" (Elan, 2003).

Moreover, our content analysis of the cases discovered workplace safety concerns were employed as a defensive routine for organizations to justify their discriminatory practices against workers with disabilities. Northwest Airlines utilized this tactic when accused of not hiring a qualified job applicant for an aircraft cleaner position because she had monocular vision. Northwest Airlines asserted

The job classification in question involves working with heavy equipment used in passenger-loading and fueling operations. The airline is fully aware of the requirements of the ADA and we work to place qualified individuals into Northwest jobs within the confines of its safety standards ("Northwest Airlines," 2001).

Comparable to safety justifications, other examples of organizational defensive routines made reference to institutional policies to defend and excuse firm discrimination (Scott, 1987). Interestingly, the existence of formalized anti-discrimination policies (e.g. EEOC statements) often allows organizations to view discrimination incidents as anomalies or infrequent occurrences. Over time these anti-discrimination policies become legitimized through their rulelike status and create the appearance that discrimination cannot exist in the organization. United Parcel Service is one example of an organization responding to allegations of job discrimination by referencing its institutionalized policies. During its 2002 discrimination lawsuit of an employee with diabetes, UPS spokesman Norm Black

\footnotetext{
${ }^{3}$ The Court of Appeals for the Second Circuit reversed and dismissed DiSanto's ADA claim, finding that he was not a qualified individual with a disability (DiSanto, 2000).
} 
stated that " $[\mathrm{t}]$ he company doesn't discriminate against people with diabetes, but it doesn't apply 'blanket' policies to diabetics... The company policy is to conduct assessments on an individual basis" (Associated Press Newswires, 2002).

By referencing institutional procedures during an image-threatening event, firms attempt to decouple the organization from the situation (Elsbach, 1994; Oliver, 1991). By doing so, the organization fails to look inward and critically reflect on the work environment inadvertently contributing to the discrimination problem. Thus, when defensive routines are enacted, the opportunity for learning how to behave differently may diminish, leaving the firm susceptible to additional allegations of discrimination.

\section{Reliance on Reactive Learning}

Another dysfunctional organizational routine is one grounded in what Argyris (1977) identified as single-loop or reactive learning. Reactive learning is not necessarily better or worse than reflective learning. It is appropriate for routine or repetitive issues, whereas reflective learning is appropriate for complex, non-routine occurrences (Argyris, 1990). The frequency with which discrimination claims are made indicates that these situations are not necessarily routine problems, but rather are complex and idiosyncratic. As such, they represent situations that are difficult to manage and therefore call for reflective learning strategies (Senge, 1990). The organizations in our study tended to adopt reactive learning strategies for managing discrimination allegations. In so doing, they failed to learn what factors within the organization could be seen as the cause of the problem and ultimately failed to resolve those specific issues (Thomas \& Ely, 1996).

To illustrate our point about reactive learning routines, we refer back to the WalMart cases in our study. In previous lawsuits, Wal-Mart entered into a voluntary consent decree with the EEOC for violations of the ADA and paid punitive damages. However, as stated, Wal-Mart continues to violate the ADA guidelines; that is, it appears easier for Wal-Mart to pay monetary fines than to engage in an investigation to determine what specific HR policies are problematic.

Moreover, because the changes were imposed externally, rather than suggested and implemented by the organization's own policy-makers, the resolution fails to address the relevant issues. By not questioning why the firm was accused of discriminatory behavior, Wal-Mart did not benefit from the deeper-level understanding that results from reflective (double-loop) learning, as described by Argyris (1977). Because of a myopic focus on minimizing costs, it is likely that reactive learning will maintain or increase discriminatory behavior within an organization.

Interestingly enough, after repeated offenses, the court system has attempted to facilitate reflective learning into Wal-Mart's employment practices to guard against future acts of discrimination, as reflected in a press release by the EEOC:

Wal-Mart is also required to make improvements to its internal procedures for providing reasonable accommodations to individuals with disabilities and will conduct extensive training next month on disability discrimination... In addition, Wal-Mart will conduct semi-annual meetings with job developers who work with the disability community to discuss current and anticipated job opportunities (EEOC, 2001). 


\section{Window Dressing}

In addition to complying with mandates imposed by the legal system, the "window dressing" of organizational policies can be a by-product of reactive or single-loop learning. Window dressing, as the term implies, is a superficial commitment to the concern of individuals with disabilities. Without a deeply seated change of managerial practices, organizational learning does not occur. Window dressing is evident in Wal-Mart's compelling national advertisements featuring people with disabilities as valued employees. However, this image does not align with the firm's employment practices (EEOC, September 20, 2001).

This employment practice has not gone unnoticed. In Boyle's (1997) study, one disabled individual expressed that window-dressing organizations are more concerned about projecting a positive image than in making a commitment to helping members of disabled populations. She contended that "compliance with the ADA is really doing the least to appear the most"' (p. 263).

Within our sample of lawsuits, we found the Venice, Florida City, Government to be another illustration of an organization engaging in "window dressing" while struggling with learning how to create an inclusive work environment for disabled employees. In 2002, Venice's City Government was recognized as the most disability-friendly city in the nation and awarded $\$ 25,000$ for its efforts from the National Organization on Disability (Brooks, 2002). During the same time, senior police clerk Thomas Hodgetts filed a federal lawsuit, supported by the EEOC, alleging Venice violated the ADA (Brooks, 2002). Venice's human resource management department failed to consider Hodgetts for a promotion and added new physical qualifications to the job description.

\section{Lack of Vicarious Learning}

Lastly, we found that organizations were having difficulty implementing ADA guidelines because they had not been engaging in vicarious learning. Through interactions and observations, organizations accumulate information on resource management (Denrell, 2003). Such information serves as a basis for vicarious learning and the imitation of successful management practices. Excelling at vicarious learning requires a representative sample to be available for benchmarking, and the organization to be astute at scanning its environment. Choo (1998) describes environmental scanning as not only entailing information acquisition, but also using the information acquired to assist in planning the organization's future course of action. Scanning plays an important role in the learning process for adverse event and risk management by detecting information as part of an organization earlywarning system (MacIntosh-Murray, 2002).

To engage in vicarious learning, organizations need a reference point. There are few reference points for successful ADA implementation. Our research found two factors contributing to the lack of reference points. First, compared to other civil rights laws, the $\mathrm{ADA}$ is a relatively new law. Even if an organization succeeds in other areas of workforce diversity management, it may still be charting its course for accommodating disabled employees (Macy, 1996). Thus, organizations have a small sample from which to learn the skills needed for ADA compliance. This can be 
compounded by the fact that people with disabilities are often unwilling to make accommodation requests because of stigmatization fears (Baldridge \& Viega, 2001).

Second, there is less interest group mobilization when organizations violate the ADA. Interest groups such as the National Organization of Women (NOW) and Jesse Jackson's Rainbow Coalition develop standards of behavior and recommend corrective actions for discriminatory behavior in the workplace (James \& Wooten, 2000). For instance, NOW labeled Wal-Mart a "merchant of shame" and called for a boycott because of the company's unfair human resource management practices, including its discrimination of disabled workers (Bull, 2002).

Coercive pressures from external stakeholders may compel organizational decision-makers to learn how to prevent discrimination against employees with disabilities in the workplace, since organizations are particularly sensitive to external audiences. Thus, consistent with the tenets of institutional theory, and coercive isomorphism in particular, organizations are likely to engage in vicarious learning, so that their behavior can conform to or comply with norms and expectations held by other organizations on which they are dependent for approval and legitimacy (DiMaggio \& Powell, 1983). This vicarious learning develops from the normative guidelines created by the energy of activist groups. Activist groups, such as NOW and the Rainbow Coalition, filter legal doctrines by assigning normative values and enabling organizations to establish cognitive frameworks, which define appropriate organizational behaviors (Edelman \& Suchman, 1997). Nonetheless, we were unable to locate cases of groups representing the disabled that mobilized stakeholders against an organization because of its discriminatory policies.

\section{LEARNING TO MANAGE DISABILITY IN THE WORKPLACE}

Some organizations excel at learning and are less vulnerable to future diversity dilemmas as a result of their proactive stance. Being proactive involves leadership actively seeking out disabled people and their skills (Woodhams \& Danieli, 2000), acknowledging the different needs of disabled employees, and modifying organizational practices to meet their needs.

Some organizations that are succeeding at creating a disability-friendly work environment incorporate this proactive behavior into their mission. For example, TecAccess (n.d.) employs over 30 associates with disabilities to help clients develop technology that is accessible and useable. Embedded in its strategic goals is a mission to help persons with disabilities become productive and independent through employment.

Similar to TecAccess, Reelbooks.com (2002) was launched to reduce the $70 \%$ employment rate among blind, working age adults. To customers, Reelbooks.com is an online audio bookstore. For its employees, it is a unique facility with assistive technology, allowing individuals who are visually impaired to perform daily work responsibilities.

Many businesses can learn by partnering with non-profit organizations and governmental agencies (Whiting, 2001). The Boeing Company participates in public-private partnerships that promote the hiring of disabled workers. Boeing partners with Metropolitan Employment and Rehabilitation Service (MER) to hire 
individuals with disabilities for temporary clerical support. The human resource specialist at Boeing acknowledges the benefits of hiring disabled workers, "Disabled people often work harder - they want to show they can do the job as well as someone else. It's a matter of pride" (Whiting, 2001, p. 22). Yet he realizes the challenges of eliminating discriminatory routines:

One of the hardest things to do is to keep an obvious disability from immediately disqualifying an applicant at the operations level... Supervisors often have no experience with disabilities, and they need to be convinced that the person can do the job. We make it a practice to do so. One supervisor objected to hiring of a very experienced, hearing impaired sheet metal worker, saying "I can't have someone who can't hear working in my sheet department." After he understood that the man had been working successfully in sheet metal for ten years, everything was fine, and the employee is still on the job (Whiting, 2001, p. 22).

The Boeing story illustrates that organizations can make it a practice to alleviate learning barriers. Many tactics employed to accomplish this are not costly and only demand a change in the cultural values and behaviors that organizations endorse or condemn (Mergenhagen, 1997). In fact, surveys conducted by both the John J. Heldrich Center for Workforce Development and the United States Department of Labor suggest the cost of accommodating disabled workers averages less than 500 dollars, and in many instances there was no need for structural accommodations but, rather, a change in human resource management practices (Dixon, Kruse, \& Van Horn, 2003; U.S. Department of Labor, 1996). Moreover, employers reported that the benefits of the accommodations to the overall organization outweighed the expenses.

\section{CONCLUSION}

This project began by examining linkages between theories of organizational learning and failure to prevent discrimination of employees with disabilities. With this goal, the researchers collected archival case study data of discrimination lawsuits brought by employees with disabilities. Through our analysis of these data, we found that the barriers to learning are embedded in complex defense mechanisms and discriminatory organizational routines. Furthermore, organizations have difficulties engaging in higher-order and vicarious learning.

Therefore, in closing, we contend that organizations should take responsibility for learning how to comply with the ADA. Facilitating this learning process requires organizations to acknowledge that barriers do exist and to understand that they can overcome these barriers. However, to overcome learning barriers, an organization needs to change its mental model by eradicating dysfunctional organizational routines. In addition, creating a disability-friendly work environment demands higher-order learning to challenge the organizational routines that hinder managing a diverse workforce. Hence, organizations should stop "window dressing" to appear disability friendly and instead engage in reactive, reflective, and vicarious learning to develop effective routines that prevent discrimination. The result may be a work environment where employee differences are leveraged. If organizations want to make jobs accessible for the disabled, they must move beyond the physical architect and consider the social 
architect, that is, the organizational culture that values and encourages fair treatment of disabled employees.

\section{APPENDIX. SAMPLE OF FIRMS EXPERIENCING DISABILITY DISCRIMINATION LAWSUITS}

\begin{tabular}{|c|c|c|}
\hline Firm & Type of disability & Discrimination charge \\
\hline Anderson Fuel \& Lubricants & Physical (heart disease) & Job demotion after surgery \\
\hline Anheuser Busch & Physical & $\begin{array}{l}\text { Job termination \& reasonable } \\
\text { accommodations }\end{array}$ \\
\hline Arkansas Municipal League & Physical (renal disease) & $\begin{array}{l}\text { Job termination \& reasonable } \\
\text { accommodations }\end{array}$ \\
\hline AT\&T & Physical (photo-phobia) & Reasonable accommodations \\
\hline Crowley Marine Services & Physical (multiple sclerosis) & Failure to accommodate; job termination \\
\hline Datanet & Physical (brain injury) & Job termination; emotional distress \\
\hline Delta Airlines & $\begin{array}{l}\text { Physical } \\
\text { (work-related injury) }\end{array}$ & Benefits discrimination \\
\hline DynCorp & Physical (Hypertension) & Pre-hiring; job application process \\
\hline Exxon Corporation & Substance abusers & Job category discrimination \\
\hline Federal Express & $\begin{array}{l}\text { Physical } \\
\text { (back \& foot injury) }\end{array}$ & Job termination after injury \\
\hline Federal Express & $\begin{array}{l}\text { Physical } \\
\text { (short-term disability) }\end{array}$ & Reasonable job accommodations \\
\hline Fred Meyer & Physical (back injury) & Harassment during employment \\
\hline General Motors & Physical (back injury) & $\begin{array}{l}\text { Hostile work environment; } \\
\text { discriminatory treatment }\end{array}$ \\
\hline General Motors & Physical (leg amputation) & $\begin{array}{l}\text { Failure to accommodate during } \\
\text { employment }\end{array}$ \\
\hline Hertz & Mentally challenged & $\begin{array}{l}\text { Reasonable accommodations; job } \\
\text { termination }\end{array}$ \\
\hline Home Depot & Mentally challenged & $\begin{array}{l}\text { Job termination; reasonable } \\
\text { accommodations }\end{array}$ \\
\hline Home Shopping Network & $\begin{array}{l}\text { Physical } \\
\text { (myasthenia gravis) }\end{array}$ & Job demotion \& termination \\
\hline $\begin{array}{l}\text { Hughes Missile Systems } \\
\text { (Raytheon) }\end{array}$ & Physical (drug addiction) & Job reinstatement \\
\hline $\begin{array}{l}\text { Illinois Dept. of } \\
\text { Human Services }\end{array}$ & $\begin{array}{l}\text { Physical } \\
\text { (intestinal, vision \& hearing }\end{array}$ & Reasonable accommodation; harassment \\
\hline Kmart & Mentally challenged & Pre-employment during the hiring proces \\
\hline Life Companion & Physical (panic disorder) & $\begin{array}{l}\text { Reasonable accommodation; job } \\
\text { termination }\end{array}$ \\
\hline McDonald's Corporation & Physical (obesity) & Pre-employment during the application \\
\hline McDonald's Corporation & Physical (face disfigurement) & Promotion denial \\
\hline McGraw-Hill & Physical (HIV positive) & Job termination after diagnosis \\
\hline Memorial Hospital & $\begin{array}{l}\text { Physical } \\
\text { (obsessive-compulsive } \\
\text { disorder) }\end{array}$ & Failure to engage in the interactive process \\
\hline Naperville City Government & Physical (bronchitis) & Denial of job transfer; harassment \\
\hline Naperville School District & Physical (leg injury) & Job demotion after injury \\
\hline Northwest Airlines & Physical (diabetes) & $\begin{array}{l}\text { Applicant discrimination after } \\
\text { physical examination }\end{array}$ \\
\hline Northwest Airlines & Physical (vision) & Pre-employment job discrimination \\
\hline Olive Garden & Mentally challenged & Harassment \\
\hline Palm Beach County & Physical (back injury) & Job-transfer discrimination \\
\hline Pimalco, Inc. & Physical (diabetes) & Job termination after diagnosis \\
\hline R. R. Donnelly \& Sons & $\begin{array}{l}\text { Physical } \\
\text { (paraplegic; incontinence) }\end{array}$ & $\begin{array}{l}\text { Job termination; reasonable } \\
\text { accommodations }\end{array}$ \\
\hline
\end{tabular}




\begin{tabular}{|c|c|c|}
\hline Firm & Type of disability & Discrimination charge \\
\hline Renaissance Roofing & Mentally challenged & Harassment \\
\hline Sampson-Bladen Oil Co & Physical (HIV positive) & Job demotion \\
\hline Sears & Physical (blind) & $\begin{array}{l}\text { Reasonable accommodations-job } \\
\text { reassignment }\end{array}$ \\
\hline Target & Physical (multiple sclerosis) & Job discrimination (during employment) \\
\hline Union Oil & Physical (sleep disorder) & Job termination after diagnosis \\
\hline United Blood & General policy & Job termination after 120 days of disability \\
\hline United Parcel Services & Physical (deaf) & $\begin{array}{l}\text { Job discrimination \& exclusion } \\
\text { of job categories }\end{array}$ \\
\hline United Parcel Services & Physical (diabetes) & $\begin{array}{l}\text { Reasonable accommodations-job } \\
\text { reassignment }\end{array}$ \\
\hline United States Bancorp & Physical (diabetes) & Reasonable accommodations \\
\hline US Airways Group & Physical (back injury) & Job demotion \\
\hline Venice City Government & $\begin{array}{l}\text { Physical } \\
\text { (neck \& leg handicapped) }\end{array}$ & Job promotion \\
\hline $\begin{array}{l}\text { Veterans Affair } \\
\text { Medical Center }\end{array}$ & Physical (deaf) & Harassment; failure to provide interpreter \\
\hline Voss Electric Company & Psychiatric (bipolar disorder) & Job termination during hospitalization \\
\hline Wal-Mart & Physical (hearing impaired) & Job termination-failure to perform \\
\hline Wal-Mart & $\begin{array}{l}\text { Physical } \\
\text { (general; } 13 \text { different suits) }\end{array}$ & Pre-employment screening \\
\hline Wal-Mart & Mentally challenged & $\begin{array}{l}\text { Reasonable accommodations } \\
\text { during employment }\end{array}$ \\
\hline Wal-Mart & Physical (leg injury) & Pre-employment job discrimination \\
\hline Wal-Mart & Physical (brain surgery) & Job demotion; job termination \\
\hline Wal-Mart & Physical (cerebral palsy) & Pre-employment screening \\
\hline Wal-Mart & Physical (leg injury) & $\begin{array}{l}\text { Reasonable accommodations } \\
\text { during employment }\end{array}$ \\
\hline
\end{tabular}

\section{REFERENCES}

Aguilera, D. C. (1990). Crisis intervention: Theory and methodology (6th ed.). St. Louis: Mosby.

Alder, P. (1999). Building better bureaucracies. The Academy of Management Executive, 13, 36-59.

Alder, P., \& Borys, B. (1996). Two types of bureaucracy: Enabling and coercive. Administrative Science Quarterly, 41, 61-89.

Argyris, C. (1977). Double loop learning in organizations. Harvard Business Review, 55, 115-125.

Argyris, C. (1990). Overcoming organizational defenses. Boston, MA: Allyn and Beacon.

Argyris, C., \& Schon, D. A. (1978). Organizational learning: A theory of action perspective. Reading, MA: Addison-Wesley.

Associated Press Newswires. (2002, September 5). EEOC sues UPS over alleged discrimination.

Baldridge, D., \& Veiga, J. (2001). Towards a greater understanding of the willingness to request an accommodation: Can requesters' beliefs disable the American with disabilities act. Academy of Management Review, 25, 85-99.

Benoit, W. L. (1995). Accounts, excuses, and apologies: A theory of image restoration strategies. Albany, NY: State University of New York Press.

Blanck, P., \& Schartz, H. A. (2001). Toward researching a national employment policy for persons with disabilities. In 22nd Mary E. Switzer memorial seminar: Emerging workforce issues: WIA, ticket to work, and partnerships. Alexandria, VA: National Rehabilitation Association.

Blanck, P., Schur, L., Kruse, D., Schwochau, S., \& Song, C. (2003). Calibrating the impact of the ADA's employment provisions. Stanford Law and Policy Review, 14(2), 267-290.

Boyatzis, R. (1998). Transforming qualitative information. Thousand Oaks, CA: Sage.

Boyle, M. (1997). Social barriers to successful reentry into mainstream organizational culture: Perceptions of people with disabilities. Human Resource Development Quarterly, 8, 259-269.

Braddock, D., \& Bachelder, L. (1994). The glass ceiling and persons with disabilities. Washington, DC: U. S. Department of Labor, Glass Ceiling Commission.

Brooks, R. (2002, July 6). Disability-friendly award tempered by employee's discrimination suit. Sarasota Herald-Tribune, p. BV1.

Bull, Cristina. (2002). NOW declares Wal-Mart a merchant of shame. National NOW Times, 34, 5. 
Choo, C. (1998). Information management for the intelligent organization: The art of scanning the environment. Medford, NJ: Information Today.

Colker, R. (2001). Winning and losing under the American Disabilities Act. Ohio State Law fournal, 62, 240-278.

Cox, T. (2001). Creating the multicultural organization: A strategy for capturing the power of diversity. University of Michigan Business School Management Series. San Francisco, CA: Jossey-Bass.

Crampton, S., \& Hodge, J. (2003). The ADA and disability accommodations. Public Personnel Management, 32, 143-154.

Cyert, R., \& March, J. G. (1963). A behavioral theory of the firm. Englewood Cliffs, NJ: Prentice-Hall.

Denrell, J. (2003). Vicarious learning, under-sampling of failure and the myths of management. Organization Science, 14, 227-243.

DeLeire, T. (2001). Changes in wage discrimination against people with disabilities: 1984-93. Fournal of Human Resources, 36, 144-159.

DiMaggio, P., \& Powell, W. (1983). The iron cage revisited: Institutional isomorphism and collectively rationality in organizational fields. American Sociological Review, 48, 147-160.

DiSanto v. McGraw-Hill, Inc., 220 F.3d 61 (2d Cir. 2000).

Dixon, K., Kruse, D., \& Van Horn, C. (2003). Series Americans attitudes about work, employers and government work trends. Restricted access: A survey of employers about people with disabilities and lowering barriers to work. New Brunswick, NJ: John J. Heldrich Center for Workforce Development.

Dodgson, M. (1993). Organizational learning: A review of some literature. Organization Studies, 14, 375-394.

Edelman, L., \& Suchman, M. (1997). The legal environment of organizations. Annual Review of Sociology, 23, 479-515.

EEOC. (2002, December 16). Donnelley to pay \$150,000 to parapelegic graphics technician for job bias. Retrieved September 21, 2004, from http://www.eeoc.gov/press/12-16-02.html

EEOC. (2004a). Americans with Disabilities Act of 1990 (ADA) charges FY 1992-FY 2003. Retrieved September 21, 2004, from http://www.eeoc.gov/stats/ada-charges.html

EEOC. (2004b). EEOC litigation statistics, FY 1992 through FY 2003. Retrieved September 19, 2004, from http://www.eeoc.gov/stats/litigation.html

Eisenhardt, K. (1989). Building theories from case study research. Academy of Management Review, 14, 532-550.

Elan, E. (2003). Outcome of lawsuit against McDonalds could weigh heavily on employers' view of obese applicants. Nation's Restaurant News, 37, 21-23.

Elsbach, K. D. (1994). Managing organizational legitimacy in the California cattle industry. Administrative Science Quarterly, 39, 57-73.

Elsbach, K. D., \& Sutton, R. I. (1992). Acquiring organizational legitimacy through illegitimate actions: A marriage of institutional and impression management theories. Academy of Management Fournal, 5, 532550.

Equal Employment Opportunities Commission. (2001, September 20). Wal-Mart agrees to air TV ad and pay $\$ 427,500$ after court finds retailer in contempt of court. Retrieved, December 17, 2003 from http://www.eeoc.gov/press/9-20-01.html

Equal Employment Opportunities Commission. (2003, January 15). Target Corp. to pay $\$ 95,000$, implement training for failure to accomodate disabled worker. Retrieved, December 17, 2003 from http://www.eeoc.gov/press/1-15-03-b.html

Fine, M., \& Asch, A. (1988). Disability beyond stigma: Social interaction, discrimination, and activism. fournal of Social Issues, 44, 3-21.

Forster, N. (1994). The analysis of company documentation. In C. Cassell, \& G. Symon (Eds.), Qualitative methods in organizational research: A practical guide (pp. 147-166). Thousand Oaks, CA: Sage.

Fraser v. Goodale, 342 F.3d 1032 (9th Cir. 2003).

Glaser, B., \& Strauss, A. (1967). Discovery of grounded theory. New York: de Gruyter.

Glynn, M. A., Lant, T. K., \& Milliken, F. J. (1994). Mapping learning processes in organizations: A multilevel framework linking learning and organizing. Advances in Managerial Cognition and Organizational Information Processing, 5, 43-83.

Hall, F., \& Hall, E. (1994). The ADA: Going beyond the law. Academy of Management Executive, 8, 17-32.

Harlan, S., \& Robert, P. (1998). The social construction of disability in organizations. Work and Occupations, 25, 397-437.

Hemphill, H., \& Haines R. (1997). Discrimination, harassment, and the failure of diversity training: What to do now. Westport, CT: Quoram.

Higuera, Fischer, \& Fischer. (2001). Wal-Mart ads to show two who sued firm. Arizona Daily Star, September 20, D1.

Hill, C. E., Thompson, B. J., \& Williams, E. N. (1997). A guide to conducting consensual qualitative research. The Counseling Psychologist, 25, 517-573.

Huber, G. (1991). Organizational learning: The contributing processes and the literature. Organization Science, 2, 88-115. 
Jackson, S. E., \& Dutton, J. E. (1987). Categorizing strategic issues: Links to organizational action. Academy of Management Review, 12, 76-90.

James, E. H., \& Wooten, L. P. (2000). Being in the spotlight: How firms respond to public diversity crises. Paper presented at the Academy of Management meeting, Toronto, BC.

Levitt, B., \& March, J. (1988). Organizational learning. Annual Review of Sociology, 14, 319-340.

Locke, K. (2001). Grounded theory in management. Thousand Oaks, CA: Sage.

MacIntosh-Murray, A. (2002). Scanning and vicarious learning from adverse events in health care. Information Research, 7, 1-20.

Macy, G. (1996). Accommodating employees with disability: A matter of attitude. Fournal of Managerial Issues, 8, 78-92.

Matthews, J. (1996). Organizational foundations of economic learning. Human Systems Management, 15, $113-124$.

McMorris, F. (1999, March 16). Ex-McGraw Hill salesman wins back pay, damages. Wall Street fournal, p. B21.

Mergenhagen, P. (1997). Enabling disabled workers. American Demographics, 19, 36-43.

Miles, M. B., \& Huberman, M. (1984). Qualitative data analysis: A sourcebook of new methods. Newbury Park, CA: Sage Publications.

Miller, D. (2000). A note on representation of environmental risks in the news. The Qualitative Report, 4, 1-8.

Northwest Airlines; EEOC sues, alleging bias against disabled applicant. (2001, June 4). Wall Street Fournal, p. A4.

National Organization on Disability. Employment facts about people with disabilities in the United States. Retrieved December 12, 2003 from http://www.nod.org

Nystrom, P., \& Starbuck, W. (1984). To avoid organizational crisis unlearn. Organizational Dynamics, Spring, 53-65.

Oliver, C. (1991). Strategic responses to institutional processes. Academy of Management Review, 16, 145179.

Pearson, C. M., \& Mitroff, I. (1993). From crisis-prone to crisis prepared. Academy of Management Executive, 7, 48-59.

Rahim, M. (1997). Managing organizational learning. International fournal of Organizational Analysis, 5, $5-8$.

ReelBooks.com. (2002). About ReelBooks.com. Retrieved September 21, 2004, from http://www.reelbooks.com/aboutreelbooks.htm

Robel v. Roundup Corp., 59 P.3d 611 (Wash. 2002).

Schafer, S., \& Helderman, R. (2001, August 2). For Wal-Mart, discontent over disabled: Mentally challenged workers' loss of jobs adds to criticism. The Washington Post, p. E1.

Schlenker, B. (1980). Impression management: The self-concept, social identity, and interpersonal relations. Melborne, FL: Krieger.

Scott, W. R. (1987). Organizations: Rational, natural, and open systems. Englewood Cliffs, NJ: Prentice-Hall.

Senge, P. (1990). The fifth discipline. New York: Doubleday.

Souza, D. (1997). The diversity trap. Forbes, 159, 83.

Stone, D., \& Colella, A. (1996). A model of factors affecting the treatment of disabled individuals in organizations. Academy of Management Review, 21, 352-401.

Strauss, A., \& Corbin, J. (1998). Basics of qualitative research: Techniques and procedures for developing grounded theory. Thousand Oaks, CA: Sage.

TecAccess.org. (n.d.). www.tecaccess.org

Thomas, D. A., \& Ely, R. J. (1996). Making differences matter: A new paradigm for managing diversity. Harvard Business Review, 74, 79-90.

U.S. Department of Labor, Office of Disability Employment Policy. (1996). Cost and benefit of accommodations. Retrieved September 20, 2004, from http://www.dol.gov/odep/pubs/ek96/benefits.htm

Whiting, M. (2001). Innovative public-private partnerships: Promoting the hiring of workers with disabilities. New York: Conference Board.

Woodhams, C., \& Danieli, A. (2000). Disability and diversity-a difference too far? Personnel Review, 29, 402-415.

Wolcott, H. (1994). Transforming qualitative data: Description, analysis and interpretation. Thousand Oaks, CA: Sage.

Wooten, L., \& James, E. (2004). When firms fail to learn: The perpetuation of discrimination in the workplace. Fournal of Management Inquiry, 13, 23-33.

Workforce (2003). Donnelly to pay $\$ 150,000$ to paraplegic graphics technician for job bias. Mantra-Con Corporation, 4, 1-3.

Wright, P., Ferris, S. P., Hiller, J. S., \& Kroll M. 1995. Competitiveness through the management of diversity. Academy of Management fournal, 38, 272-290.

Yogesh, M. (1998). Deciphering the knowledge management hype. Fournal of Quality and Participation, 21, 58-60. 